\title{
Preface
}

There is something about the First World War that holds contemporary readers, and particularly American readers, at a distance. The optimism and expectations of the societies that welcomed the war are difficult for us to understand. The elevated diction used to drum up and maintain support for the war seems antiquated and obscure. Meanwhile sarcasm, humor, and satire often go unnoticed, lost in cultural, temporal, and linguistic translation. The Infantrymen of the Western Front can seem frozen in a moment far removed from our own.

If we listen beneath the cultural and temporal specificity of texts from the First World War, however, we can hear voices that are remarkably familiar to us. If we dust off these texts and remove the sepia filter through which we so often remember the First World War, we can be startled by the jarring immediacy of what is portrayed and its frightful similarity to the ways of the world today. Albert Kahn's autochrome color photographs of First World War soldiers provide this kind of shock of recognition. Seeing the trench soldier bathed in sunlight reminds us that for all that the Western Front could be monochromatic in its muddiness, it was a real place occupied by real people whose lives were as real (and as precious) to them as ours are to us.

Listening beneath the flow makes us more sensitive to similarities between the First World War moment and our own. Commonalities emerge between the outlook of the "Gen-Xers" who fought in Iraq and Afghanistan at the dawn of the twenty-first century and the "I9I 4 generation" that fought on the Western Front at the dawn of the twentieth. Both lived through a mass media and technological revolution - the explosion of the mass press at the end of the nineteenth century and the dawn of the Internet age at the end of 
the twentieth — that gave them unprecedented media outlets for their impressions of war.

Consider the case of US Infantryman Colby Buzzell. When Buzzell began his tour of duty in Iraq in 2003 , he began reading, journaling, and blogging. What resulted was a spontaneous, fragmented, and hypertextual collection of cyber anecdotes later reworked as a memoir entitled My War: Killing Time in Iraq. These anecdotes and impressions from the Iraq War are, it turns out, not that different in tone and content from the anecdotes First World War soldiers sent to the big daily newspapers and later published as novels and memoirs.

Colby Buzzell's memoir is an unvarnished look, not only at the army and the war, but also at the motivations and mentality of the modern soldier. In Buzzell's writing, the excruciating but real thrill of combat, the lure of adventure, and a residual belief in the value of the work being done in Iraq live in uneasy and unresolved tension with a cynical and disabused attitude about the futility of war, the hypocrisy of the army, the government, and the media, and the lack of understanding of the civilian population at home. Buzzell refuses to come down clearly for or against the war or the military. His point of view is constantly shifting between a critical distance from the mindset and worldview of his former machine-gunner self and an ongoing identification with, and pride in, that same mindset and worldview.

Martin Hurcombe has seen a similar "messiness" in the writings of French World War I soldiers. ${ }^{1}$ The novels and memoirs these soldiers produced are caught, he suggests, between the two poles that he calls "ideology" and the "absurd": that is, between a desire to impose some definitive structure and meaning on the war and the radical recognition that structure and meaning were precisely what the war in its chaos and violence had destroyed. Soldiers from the First World War weren't struggling with these issues alone, however, and their works were not produced in a vacuum. As Paul Fussell has so masterfully shown, they turned to literary and popular culture for tropes and techniques for putting their experiences into words. They drew upon songs, rumors, and music hall memories but also upon great booksJohn Bunyan's The Pilgrim's Progress and the Oxford Book of English Verse were particularly important. First World War soldiers used the books they had read to write about the war experiences they had lived through.

Almost a century later, Colby Buzzell would do much the same thing. Buzzell received boxes of books in the mail, and he used those books to think 
about the Iraq war. Throughout his memoir, Buzzell makes reference to the films, magazines, music, and readings that made up his cognitive and cultural toolkit while in Iraq. He claims literary allegiances and nods to literary and cinematic influences that informed the writing of "[his]" war. Among the books he mentions are Michael Herr's I977 Vietnam War memoir Dispatches and a series of books by gonzo journalist Hunter S. Thompson. Buzzell's particular narrative style and stance are aligned with those of Herr and Thompson - that is, outside of, and in opposition to, the "brainwashed rhetoric" of the army, government, and mainstream media.

Also on his list is Joseph Heller's I96r satirical novel Catch-22, set during the Second World War. The novel chronicles the attempts of the unheroic bombardier John Yossarian to stay alive and sane within and despite a bureaucratic machine bent on sending him to his death. Buzzell does not dwell on his reading of Catch-22 or single it out as having been more important than the rest of his readings in forging the particular style and sensibility expressed in his writing. But if we want to understand Buzzell's work and works like it, it is to Catch-22 that we should turn before moving even further back in time. It is not to the Second World War or the Vietnam War that we should look for the emergence of the kind of writing that would ultimately lead to $M y$ War. It is to the First World War, since the critical distance we recognize in Herr and Thompson's works and the comic tropes we recognize in Catch-22 were already in play in I9I4-I9I8.

If Buzzell's memoir is a Catch-22 for the Second Iraq War, Catch-22 itself was a Voyage au bout de la nuit (Journey to the End of the Night) for the Second World War. Buzzell's reaction to his first experience of a combat zone recalls that of Yosserian in Catch-22. But it also recalls that of Louis-Ferdinand Céline's World War I infantry soldier Bardamu in Voyage au bout de la nuit (I932). The fresh recruit Buzzell is shocked by the brutal crossing of a threshold of violence and acceptance of violence when he gets to Iraq. "Holy shit!" he remembers thinking, "People are trying to kill each other!" 2 Bardamu's reaction is similar: "So there was no mistake? So there was no law against people shooting at people they couldn't even see!" 3

Buzzell's nonchalance and lack of conviction in enlisting in the army also recall that of Bardamu who, seeing a regiment march past the café where he is sitting, suddenly decides to join up, to spite his drinking buddy and to satisfy his own curiosity. For Buzzell, as for Bardamu, things go downhill from there. "Once you sign on that dotted line and raise your hand and swear 
that you'll uphold the Constitution against enemies both foreign and domestic," Buzzell explains, "you're fucked if you want to back out."4 Bardamu's assessment is more laconic_- "When you're in, you're in,"—but equally vivid_- "We were caught like rats." 5

What My War, Catch-22, and Voyage au bout de la nuit share in common, beyond being satirical texts inspired by their authors' experiences in war, is a mood or an ethos - the picaresque. The picaresque wasn't born in the trenches of the First World War. It had been around for centuries and was reactivated during the war because it was uniquely appropriate for describing the kind of world the trenches represented - a world that is so violent, so chaotic, and so radically governed by chance that the only pattern of experience that makes any sense is that of basic, animal survival. The picaro is a protagonist with a long literary past who can serve as a model for how to scratch and scramble just to stay alive. When asked by a reader to express his understanding of the meaning of life, what Colby Buzzell came up with was a typically picaresque credo: "The meaning of life for me right now is to make it back in one piece."6

The immediate survival strategies of soldiers and civilians during the First World War have often been misconstrued or even eclipsed by postwar interpretations of the war. The works I have chosen to share in this study tell a different tale about the First World War from the one to which we are most accustomed. They provide a counter-narrative to postwar interpretations of the trench soldier as a passive victim or an active resister, focusing instead on the mechanisms through which soldiers and civilians resigned themselves to the war but imagined themselves as survivors. They were able to do so by reactivating a form of storytelling — the picaresque — whose central concern had always been the survival of a non-heroic protagonist in a harsh and hostile environment.

My aim in reading texts from the First World War has been to uncover the attitudes and outlooks of the people who lived through that war-the Great War, as they called it-one hundred years ago. My conclusion is that the same approach, sensibility, and outlook represented in the work of Colby Buzzell or Joseph Heller were already present in novels, cartoons, newspaper articles, and other media produced during and immediately after the Great War. That outlook was shared by soldiers and civilians alike, or rather it was mutually constructed through a mediatized dialogue between and among 
these groups. It is to the long and rich European picaresque tradition that we can most productively turn in our effort to understand the attitudes expressed by the people who lived through the first industrialized total war. ${ }^{7}$ The picaresque is a literary and cultural framework through which we can understand the spirit of an age - that of the First World War and its immediate aftermath - and through which we can interrogate more recent cultural artifacts born in the context of war. As a myth or a mode, the picaresque is a "permanent temptation to the human mind." An archetypal pattern for making sense of experience, the picaresque resurfaces "during days of irony and discouragement." 8

Buzzell's ambivalence about the army, the war, and the larger society that approved the war is typical of the contradictory and unstable positiontaking (or lack thereof) of many French Great War soldiers writing in the picaresque mode. The often-comic picaresque everyman that replaced the epic hero of Napoleonic legend was used to articulate a modern, popular, and Republican vision of what it meant to be French in the early twentieth century. What emerged during the war years was an ambivalent form of patriotism that was staunchly antimilitarist, but not yet pacifist, highly individualistic, but nationalistic at the same time. It is a patriotism caught between Hurcombe's alternatives of "ideology" and the "absurd," between a sense of belonging and a sense of alienation, between the pull of solidarity and the push of solitude.

That patriotism was often expressed in a tone that we recognize in Buzzell's writing. A similar sarcasm is used by Bardamu in Voyage au bout de la nuit (1932), for example, but it was already to be found in earlier Great War novels like Henri Barbusse's Le Feu (Under Fire, I916) or Roland Dorgelès's Les Croix de bois (The Wooden Crosses, I9I9). Just as Buzzell identifies with the figure of the "smartass," many Great War soldier-novelists chose to include in their narratives the figure of the gouailleur, the cocky, mocking wisecracker who calls things as he sees them and doesn't mince words.

By his own admission, the Colby Buzzell who was recruited into the army was an unambitious slacker who drank too much and worked too little, got into trouble with the police, ran his mouth and swore a lot, and acted out of a spirit of contradiction. His recruiter was unfazed by Buzzell's seeming lack of potential as a warrior. The "Army wanted quantity, not quality. They didn't give a fuck how old I was, what shape I was in, or what kind of past I'd 
had," Buzzell writes, "they'd take me." ${ }^{10}$ Life in the army and a tour of duty in Iraq didn't reform Colby Buzzell or change his habits or attitude for the better. In fact, when he describes forcing Iraqi civilians through a checkpoint, he expresses disgust at the person he had become: "I felt like the biggest fucking asshole on the planet."11

War doesn't make you better. The most you can hope for is that it doesn't make you worse. This is a point made over and over again in Great War texts that showcase unpromising soldiers who are as lacking in discipline, initiative, and respect for authority when they are demobilized as they were when they were called up. The present study is full of soldier characters who resemble the persona crafted by Buzzell in his memoir. They are jacks-ofall-trades, small-time crooks and con artists, cowardly loafers, wine guzzlers, and foul-mouthed hotheads. It is in their ability to do their jobs as soldiers without being robotized, militarized, or completely brutalized, and not in their courage, self-sacrifice, or ambition, that their heroism lies. In 2004 as in I9I 4 , there was, to borrow from Tim Cook, "space for the hero and the anti-hero to sit comfortably together within the soldiers' culture."12 Throughout the twentieth century and into the twenty-first, such tensions and contradictions have been at the heart of soldier self-imagining and iconography.

There are many more parallels that can be drawn between Buzzell's treatment of the Iraq War and the writing of soldiers who fought in the First World War. They share a similar poetics - a present-tense immediacy, a discontinuous and episodic narrative structure, an irreverent and conversational tone, the use of soldier slang and soldier dialogues, and the insertion of intertexts, including newspaper articles and pastiches. They share a similar pacing, alternating between scenes of combat and scenes of daily life. They share a similar thematics of hypocrisy, illusions, misinformation, and dissimulation. The soldier is both critical of, and complicit with, government, army, and media brainwashing. They describe a similar rift in experience between those who experience the war firsthand, and those who do not - between the soldier under fire and the shirker behind the lines. They also describe a similar ambivalence about soldier friendships — their importance for keeping up morale but also their fragility and dependence upon context. Henri Barbusse's soldier-character Lamuse sums up this ambivalence. When his "buddies are in danger," he "forgets everything" and risks his life to help them. "But otherwise, man, I’m looking out for number one."13 


\section{PREFACE XVii}

In reinventing the modern soldier as picaro, the Great War writers and artists in this study created an apt warrior for the modern age, one that would resurface throughout the twentieth century and, with Buzzell, into the twentyfirst. Their insight goes well beyond the theater of war, however. What they understood in I9I4, we are still coming to terms with today-that the picaresque is the dominant and perhaps the only viable ethos for the modern cultural imagination. 
This page intentionally left blank 